\title{
Prostate Cancer cT3b TNM Finding v8
}

National Cancer Institute

\section{Source}

National Cancer Institute. Prostate Cancer cT3b TNM Finding v8. NCI Thesaurus. Code C140142.

Prostate cancer in which the tumor invades seminal vesicle(s). (from AJCC 8th Ed.) 